\title{
Factors Responsible For The Under-Representation Of Women In Senior High School Headship In The Brong Ahafo Region, Ghana
}

\author{
Dr. Hinneh Kusi \\ Senior Lecturer, Department of Educational Administration and Management, \\ Faculty of Educational Studies, University of Education, Winneba.
}

\begin{abstract}
The study explored factors responsible for the under-representation of women in Senior High School headship in selected districts and a municipality in the Brong Ahafo region of Ghana. This was a qualitative study underpinned by the interpretive paradigm. Specifically, a case study design was employed for the study. The sample for the study consisted of 7 purposively selected headmistresses ( 5 in urban centres and 2 in semi-urban centres) of the schools. A semi-structured interview schedule was employed for data collection and the collected data was analysed thematically. The study revealed that the factors responsible for women's under-representation in the school headship included female teachers' reluctance to accept responsibilities that will prepare them for headship, unfavourable and discriminatory leadership recruitment and hiring practices, and female teachers' failure to have career development plans that include headship. Among others, the study concluded that a combination of factors, including those relating to the organizations accounted for the low representation of women in school headship in the study area. Therefore, it was recommended that the secondary school authorities should collaborate with the various education directorates in the setting of the study to organise training programmes to equip potential female leaders with leadership skills so that they could apply for headship, when necessary.
\end{abstract}

Keywords: School leadership, Headship, Female teachers, Under-representation, Women, Senior High School, Headmistress

\section{INTRODUCTION}

It is a general belief that the future of every society is reliant on education and for that matter schools. It is argued that education is an indispensable catalyst that strongly influences the development and economic fortunes of a nation and the quality of life of its people. The success of schools, however, depends on various school related factors. According to Rimmer [1] (2003), the most important activity next to classroom instruction to improve student learning is school leadership.

School leaders play crucial role in school change and school improvement [2] (Robinson, Lloyd \& Rowe, 2008). Leadership provided by school heads, both males and females, is an indispensable factor in enhancing students' achievement and for that matter the success of schools [3] (Kusi, 2008). However, over the years, school leadership, especially headship/principalship has remained a male hegemony although in most countries in the world the teaching profession is dominated by females [4] (Mythili, 2017). The perception held by many people is that management is a male notion, affecting women's representation at that level. 
Literature suggests that female school leaders, like their male counterparts, make significant contribution to the success of schools, and that both of them blend masculine and feminine management styles [5] (Coleman, 2000). Female school leaders are considered to be employing transformational, collaborative, consultative and people-oriented management styles [6] (Elms, 2004), which tend to influence the success of schools.

Over the past decades, issues concerning women have taken new dimensions and received varied treatments by the United Nations and its specialised agencies at various conferences. One of the issues that have taken the centre-stage of most discussions at such conferences is gender equality. The principle of equality of men and women was first recognised in 1945 in the United Nations Charter, and subsequently in the Universal Declaration of Human Rights in 1948. Worldwide statistics show that the number of women in managerial positions continue to increase, but the rate of progress is slow and uneven [7] (Schien, 2007). Many global conferences, including the Fourth World Conference on Women in 1995, the Cairo Conference on Population and Development in 1994 and World Summit for Social Development in 1995 have recognized that, despite the progress made globally in improving the status of women, gender disparities still exist in all sectors regarding decision making.

There is also evidence that very few women occupy headship positions in some developing countries, regardless of the widespread debates on gender equality. Mythili [4] (2017) notes that only 12.7 percent of secondary school principals are women in Tanzania; 8 percent of secondary school principals in Vanuatu were women; while in Solomon Islands and Papua New Guinea, only 2.9 percent of secondary school principals were women [8] (Jane, Shalom, Bessie, \& Daisy, 2010). Women make up the majority of the degree recipients in educational leadership in some countries, but hardly any ascend to leadership positions $[9,10]$

In Ghana many females occupy headship positions in basic schools, but it appears this has not reflected at senior high school (SHS), a three-year post-middle school system headship. For example, out of 78 Government-assisted senior high schools (SHSs) in the Brong Ahafo Region of Ghana, only 16 of them are headed by women. Despites the efforts being made by the Government of Ghana and international agencies to narrow the gap between men and women in decision-making and in terms of leadership positions, women have low representation in senior high school headship in the region. However, little is known about the factors responsible for the situation. This study explores the factors accounting for the underrepresentation of women in SHS headship in Ghana, using female headmistresses in selected districts and a municipality as a case.

The study is significant in diverse ways. Firstly, the findings of the study could create awareness among education authorities in the study area and female heads in particular, on the factors responsible for the low representation of women in headship. Knowing this could help them strategise to overcome such 'glass- ceilings'. Secondly, the findings could form the basis of local policy on women's representation in school headship in the study area. Last, but not the least, the study could form the basis of further studies into gender and school leadership in Ghana, and contribute to literature on that issue.

\section{THE STUDY SETTING}

This study was conducted in Senior High Schools (SHSs) in Dormaa Central, East and West districts, Sunyani East district, Sunyani Municipality, and Jaman South district, located in the Brong Ahafo Region in the midlands of Ghana. The setting has both urban and semi-urban areas with the inhabitants (who are Akans), engaging in business and farming as their major occupations. There are other people in the area who work in both the formal and informal 
sectors. With regard to education, the study area has a number of pre- secondary and some post-secondary institutions.

\section{THE CONCEPT OF EDUCATIONAL LEADERSHIP}

The term leadership could be defined as the ability to influence individuals to work toward the attainment of organisational goals or objectives [11](Mankoe, 2007). Leadership can also be seen as a process whereby an individual influences a group of individuals to achieve a common goal [12] (Northouse, 2018). Educational leadership is viewed as a process by which someone as the head of an educational organization influences subordinates towards the achievement of educational goals [13] (Makura 2008). It has long been seen as a key factor in school effectiveness and much interest in educational leadership has increased over the years. This is due to a number of factors, often related to political demands placed on the education systems. There is an increasing consensus among researchers in the field of educational leadership and management, in both advanced and developing countries, that the leadership provided by school heads is absolutely crucial for the success of schools [14, 15] (Bush \& Jackson, 2003; Simkins, 2005). Simkins [15] (2005) indicates that in the developed world this recognition has led to huge financial commitments in major initiatives that will bring about improvement in leadership and management.

Educational leaders influence and manage pedagogical goals and visions underpinning instructional programmes to promote teachers learning and development for students' improvement [16] (Searby \&Tripses, 2006). Gobena [17] (2014) argues that educational leaders enhance students' outcomes through the creation of an environment which promotes student learning. Thus, leadership roles of school heads, both males and females, are crucial for the success of schools. However, as already noted, school headship especially at secondary level has, over the years, remained a male hegemony, although the teaching profession is dominated by females in many countries.

\section{CONCEPTUAL MODELS ON WOMEN PARTICIPATION IN SCHOOL LEADERSHIP}

Literature in the field of educational leadership and management indicate that several interrelated conceptual models have been employed to explain the under-representation of women in educational leadership. These models include the social model, organizational model, individual model and international model.

According to Gobena [17] (2014), the social model looks for explanations in women not as individuals or in educational systems, but in society as a whole. The social model considers "social structure of society as the root cause of inequities" (Shakeshaft, 2009 [18, P.83]. It assumes that "women and men have been taught to identify their roles separately" and those institutional and societal practices reinforcing these differences account for the lack of women in leadership positions [17](Gobena, 2014). In this model, young boys and girls are socialised in different ways and are institutionally reinforced well into adulthood. According to Schmuck [19] (2000), 'the folkways and norms of the society coincide with different socialization patterns and channel women and men into different areas of work, which are assigned differential pay and status' [p. 244]. The assumption of the social model is that the absence of women in leadership positions is due to the different socialization patterns of men and women [20](Asamoah, 1996). This model argues that women would move into school leadership positions if they deny societal norms and values that restrict them.

The organizational model sees men's and women's differential career aspirations and achievements, not as a function of different psychological predispositions but as an effect of the limited opportunities for women that accompany systemic gender bias [21](Tallerico \& 
Burstyn, 2006). the key argument of the model is that women do not participate in leadership because men are given special treatment in both promotional and administrative practices that are the structural and systemic barriers that work against the participation of all candidates who are not males [17] (Gobena, 2014). The organizational model assumes that "people adjust their aspirations to that which is possible and that women in education do not aspire to leadership as a result of limited opportunity" [22](Grady, 1992: 23).

According to the individual model, people are promoted based on their ability [23 in 17] (Ortiz \& Marshall, 1988 cited in Gobena, 2014). Therefore, the model argues that men occupy the most senior positions in educational institutions because they better qualified. This model implies that men are more competent than women because men are chosen for administrative positions so often. The individual model is linked to Shakeshaft's [18] (2009) "internal barriers", which places women at low status and not competent enough to occupy leadership positions in educational organizations.

The international model argues that household child-care support result in gender equality in educational leadership. However, gender equality in educational leadership will be low if the variables from international to personal level could not encourage women's aspirations to school and women's access to educational leadership [17]( Gobena, 2014).

\section{METHODOLOGY}

This was a qualitative study underpinned by the interpretive paradigm. Specifically, a case study design was employed for the study. A case study involves '(a) an in-depth study of (b) one or more instances of a phenomenon (c) in its real-life context that (d) reflects the perspective of the participants involved in the phenomenon'[24, p.447]. (Gall, Gall \& Borg, 2007: 447). A case study aims to understand the case in-depth, and in its natural setting, recognizing its complexity and its context. This design was employed for the study because my aim was to explore the views of the female heads on their under-representation in SHS headship in a well-defined geographical area.

The population of the study comprised all female headmistresses of SHSs in the Brong Ahafo Region of Ghana. The accessible population were those in Dormaa Central, East and West Districts, Sunyani East district and Sunyani Municipality, and Jaman South district. These places were chosen as the study setting since there were adequate number female heads who could provide relevant data for the study. The sample for the study comprised 7 female heads of SHSs in selected districts and a municipality in the Brong Ahafo Region of Ghana. These participants were purposively selected for the study. Purposive sampling enables the inclusion of samples with special interest to the researcher. Participants are purposefully chosen because they provide information which enrich the research [25] (Patton, 1990).

Data for the study was collected through a semi-structured interviews with the female heads of the schools. In semi-structured interviews, the participant is required to answer a set of predetermined questions that define the line of inquiry and probing and clarification of answers are allowed in the conversation [26] (Kusi, 2012). In this type of interview, the researcher needs to be very attentive to the responses given by the interviewee to identify new emerging lines of inquiry that are directly related to the phenomenon being studied. The interviews focused on the organizational, socio-cultural and women-related factors identified in literature as responsible for women's under-representation in senior high school headship.

The semi-structured interview schedule was validated before being used for data collection. To establish the face validity of the instrument, it was given to colleague lecturers for their 
comments on the items as well as the structure of the questions. The content validity of the instrument was also established by some experts in educational administration and management, especially gender issues in school management. The comments of these experts were considered before the instrument was pre-tested with 3 female headmistresses in the Tano North District in the Brong Ahafo Region.

After permission had been granted to conduct the study in the settings of the study, the informed consent of the participants was sought. Data was collected through 40 minute one-toone interview with each of the participants in noise-free locations in their respective schools. The data collected was analysed thematically. The process began with transcription of the recorded data for repeated readings-this was meant to immerse myself with the data. Then, themes were identified based on issues in relevant literature and the purpose of the study. The data was then coded under relevant themes to form frameworks before description. In the descriptions, relevant quotes or comments from the participants were used to add realism to the analysis.

Out of the 7 headmistresses, 5 were heads of schools in urban centres, while 2 were in the semi-urban areas. To attribute statements to the interviewees, the 5 urban heads were given the serial numbers FUH-1 to FUH-5 where FUH represents Female Urban Head. The 2 heads in the semi-urban areas were given the serial numbers FSUH-1 to FSUH-2, where FSUH stands for Female Semi-urban Head.

Three strategies were employed to validate the findings. The first was respondent validation, which involved sending the findings back to the participants for them to determine whether they (the findings) reflect their responses. The second strategy was peer examination, which required the presentation of the findings to some colleague lecturers and some post-graduate students in educational administration and management for them to comment on the clarity of the findings and the conclusions drawn. Last, but not the least, an 'audit trail' [27.p.32] (Charmaz, 1995: 32) was employed to validate the findings. With regard to this strategy, I ensured that constructions emerged from the data, thereby confirming the findings and grounding them in the evidence.

\section{ANALYSIS AND DISCUSSION OF FINDINGS \\ Organisational Factors Responsible for the Under-Representation of Women in School Headship}

The interview data highlighted some organizational factors responsible for the underrepresentation of women in the SHS headship in the study area, and these included unfavourable job recruitment and hiring practices; lack of special support to females to win competition for leadership positions in the education system; absence of special provisions for women to attend leadership training; and the female teachers reluctance to accept responsibilities delegated to them by their heads.

The data suggested that one of the factors that account for the low representation of women in school headship in the study area was unfavourable job recruitment and hiring practices. It emerged that these practices do not attract female candidates for leadership. For example, FSUH-1 commented:

When it comes to recruitment of school heads, in most cases, the panel looks for men, not women. This makes most potential women not interested in such positions..... The person specifications always favour men, not women!... 
Similarly, Macionis and Gerber [28] (2010) found that organizational structures especially job assignment and design prevent females from ascending to the top administrative level. The findings also support the organizational model of women's under-representation in leadership positions which argues that women are under-represented because men are given special considerations in promotional and administrative practices in various organizations [19] (Schmuck's, 2000). This situation is often attributed to the assertion that "females are there [in school] to teach the leavers and men are there to run or manage the schools. The term teacher is associated with a female and head with a man" [29. p. 6] Amuzu-Kpeglo, 2005: 6).

Another factor that emerged from the interview data as accounting for the low representation of women in the headship position was lack of special support for females to win competition for leadership positions. The participants complained that the Board of Governors of the schools, and panels that appoint school heads are often dominated by males, making it difficult for females to win their support.

What I know is that if you are a woman and you want to win competition for headship, it becomes difficult. You know the school boards and the Ghana education system panels are dominated by men, so, in most cases, they all want males as heads. They hardly support women against their male counterparts[FSUH-2].

This view was also shared by FUH-3:

I attended an interview for headship before my current position. And, immediately all of us [the interviewees] were presented to the panel, a male member commented 'this job requires a man, not a woman! In the end, a male got the job!

The by FSUH-2 and FUH-3 comments suggest that women are still being discriminated against in their career progression, as school headship is still seen as male hegemony and support the organizational model [ Schmuck's [19], 2000) of women's under-representation in leadership positions. Shakeshaft [30] (1996) also asserted that cunning forms of discrimination are still a factor in female teachers' career progression. The participants believed that the appointment of secondary school heads in the context of the study are based on gender, not competence.

Also, female teachers' reluctance to accept responsibilities delegated to them by their heads seemed to serve as a barrier to their advancement into headship. The data suggested that the teachers often cited their multiple roles, including child and family care as reasons for their reluctance to accept responsibilities delegated to them.

My observation is that some of the female teachers in this school are unwilling to accept responsibilities delegated to them. They always give excuses that they have so many responsibilities at home and these affect their career progression!......[FUH-4]

The female teachers always complain that they are busy and stressed up and, therefore, are not willing to take up any more responsibilities. They complain too much about their home responsibilities [FSUH-1].

The comments that the female teacher are pre-occupied with their home responsibilities confirm the international model of women's under-representation in leadership positions which argues that women's household child-care support and domestic responsibilities result in gender equality in educational leadership [19] (Schmuck's, 2000). The comments by FUH-4 and FSUH- 1 also point out clearly that the female teachers have not embraced the importance of the concept of delegation in their career progression. Literature suggests that delegation is a way of training and developing staff to handle higher and more challenging tasks, and to build 
the confidence level of the delegatee [31] (Jones, 2008). This implies that the female teachers may be missing the opportunity to acquire relevant knowledge, skills and competences, which might affect their career progression negatively.

Two of the interviewees, however, offered different reasons for the female teachers' reluctance to accept responsibilities delegated to them. They attributed the situation to perceived lack of competence on part of the female teachers.

In most school, female teachers are seen as incompetent in handling any leadership position. Left to those heads alone, no female teacher will hold any leadership position in schools [FSUH-2].

The female teachers are being seen as not competent enough to hold some leadership positions in the school as compared to the male teachers and so leadership roles are usually given to them [FUH-2].

Similarly, literature attributes the low representation of women in educational leadership to an internal barrier of lack of confidence, and not seeing themselves as leaders [32] (Cubillo \& Brown, 2003). To Coleman [33] (1996), women do not exhibit confidence in applying for management positions because unfamiliarity with that territory than lack of faith in their abilities.

\section{Socio-Cultural Factors Responsible for the Under-Representation of Women in SHS Headship.}

The data highlighted some socio-cultural practices responsible for women's underrepresentation in school headship positions. The interviewees indicated the socialisation process in Ghanaian societies confine young females to special roles in the home, especially the kitchen without given the needed attention to their career development. The socialisation process encourages female children to be concerned with domestic roles and family issues as they help their parents with the household chores and care of their younger siblings. Their male counterparts, on the other hand, from childhood, are trained to exercise power and control over the females by taking decisions for them in most aspects of their lives. This, according to the interviewees, affected their career development and progression into headship positions.

Female children are socialised to be family-oriented so as they grow, the family becomes their priority and all other things become secondary. Female teachers, therefore, make their family their utmost concern and their career progression suffers. This is contrary to what happens to their male counterparts[FUH-5].

From childhood, the girls are trained to be care-givers and mothers so their concern, as they grow to become adults, is on the care of the family members and the home rather than aspiring higher in their career, hence, their inability to advance to SHS headship [FUH-3].

FSUH-1 shares this view, commenting:

Women are to take care of the home while the men go out to fend for the family. That is how we have been socialised in Ghana. So, it is fine for a female teacher to remain as such so she could get time for her core duties which is taking care of the home and the family. This will obviously affect career development.

One of such factors from the data was that in the Ghanaian traditional society, female children are socialised to be family-oriented. This implies that, they are brought up to be concerned 
with domestic duties and family issues such as taking care of their younger siblings, among others. Female teachers, therefore, make family issues override their career development which would help them become heads of senior high schools. Even should they become school leaders, they face challenges due to roles conflict resulting from roles they play as mothers, wives, daughters and managers [34] (Agyeiwaa \& Attom, 2018). Adler and Israeli [35] (1998) asserted that traditional attitudes towards women's family roles, and women's minimal access to social networks are the barriers to women's aspiration for leadership.

The data also indicated that through the socialisation process, male and female children are assigned some specific duties and responsibilities. The Ghanaian society make women consider themselves as mothers, nurturers and care-givers, and leave decision-making and leadership roles to men. These gender-based roles, according to the interviewees, are not relevant in the work-places, but are unconsciously recognised by the female teachers.

Females have been socialised to be concerned with domestic duties which involves taking care of the home and family, while the male go out to fend for the family. Therefore, female teachers are not concerned with leadership roles since from their socialisation, they [leadership roles] are meant for the men[FSUH-2].

We were made to accept, through our socialisation, that a woman's priority is to take care of the family and support her husband. Because of this, most female teachers concentrate on family duties and forget about career development which will enable them to climb to the top or become a headmistress[FUH-4].

Thus, the data suggested that gendered social roles deny women the opportunity to carry out certain roles and responsibilities, affecting their progression into school headship. Agyeiwaa and Attom [34] (2018) noted that cultural beliefs and traditional perceptions on gender roles continue to serve as a barrier to women leaders and argued that these challenges constitute social constraints that overshadow their leadership qualities.

It also emerged from the data that another socio-cultural factor that impeded women from ascending into school headship was the socialisation process of making females submit to men and the men socialised to be lords over females. To the participants, it was normal for the male teachers to become heads and their female counterparts their subordinates.

In our traditional homes, the men are the heads while the women are their subordinates. That is how we have been trained, so female teachers are not inspired to take up leadership roles. They have been trained not to exercise power over males[FUH-1].

We have been socialised to accept that the men are the heads so female teachers do not see the need to aspire to be heads. Their position as teachers is enough for them, especially those with rigid traditional beliefs[FUH-5].

As girls, when we were growing up, we were trained to submit to our male counterparts. So, how can a woman be the head of a school where there are male teachers that she is supposed to submit to?[FSUH-2]

The data suggested that most of the female teachers feel comfortable playing their role as followers and people who submit to the men as that conforms to social norms in Ghana. This notion seems to confirm a report by UNESCO in 2000 that femininity is associated with submissiveness, gentleness, emotional dependence and not quite good at decision making and tactfulness, while characteristics associated with masculinity are dominance, aggressiveness, 
not emotional, blunt, independence and very good at decision making. It appears these highlighted characteristics associated with women impede the female teachers from participating in school leadership.

Some Christian religious beliefs and principles emerged as factors that have further socialised women to submit to their male counterparts. The interviewees made references to the scriptural teachings that admonish women to submit to men in obedience to God and believed these teachings as contributing to women's seemingly reluctance to ascend into school leadership.

As children, we are taught as girls to be submissive to the boys in the house. As we grow, we are taught by the Bible as wives to submit to our husbands, so we tend to see ourselves as going wayward when we become leaders over our male counterparts. Most female teachers, therefore, see it normal to remain subordinates to men or their male counterparts[FUH-3].

We are socialised as women to be submissive to men in accordance with what the Bible says. It [the Bible] says that wives should be submissive to their husbands. Therefore, female teachers see it normal to be subordinates to male heads [FUH-5].

These comments suggest that people who adhere strictly to these Biblical teachings may see females as subservient to males, and constitutes social constraints that overshadow women's leadership potentials [34].(Agyeiwaa \& Attom, 2018). The comments further suggested that competing with men for headship is tantamount to disobedience to Biblical teachings, a notion which could account for women's low representation in the senior high school headship.

Thus, the study revealed that the under-representation of women in school headship positions could be explained using the social model, which argues that socialization processes and social structures account for inequalities between men and women in leadership [19].(Schmuck's, 2000).

\section{Women's Personal Factors Responsible for their Under-Representation in School Headship}

The interviewees were asked whether there are some factors that are related to women, which are responsible for their under-representation in SHS headship. Most of them believed, to an extent, women could be blamed for their under-representation in headship and gave various reasons for their assertion.

Some of the interviewees complained that most of the female teachers do not have the required qualifications for headship. According to the Ghana Education Service regulation, one can be an SHS head if she is at the rank of Deputy Director at or before the age of fifty-five (55), and interviewees believed most female teachers do not attain this rank until they retire or attain it after the stipulated years.

Some female teachers would have wished to become heads of SHSs but the qualification is not there. One is supposed to be a Deputy Director before being in that position [headship], but most female teachers do not attain that rank[FUH-1].

Female teachers are unable to become SHS heads because they do not have the required qualification to enable them be there. What qualifies one to be a head is to be a Deputy Director and, recently, to hold a second degree of which most female teachers lack. Therefore, they do not become heads[FSUH-1]. 
Thus, the females' inability to obtain required professional qualification or rank for headship limited them from assuming headship in the SHSs. This finding confirm the argument of the individual model that people are promoted based on their ability [23] (Ortiz \& Marshall, 1988), and that men occupy the most senior positions in school headship because they hold the best qualifications [19] (Schmuck's, 2000),implying they are more competent than women. Contrary to this finding, McNamara, Howson, Gunter, Sprigade and Onat-Stelma[36] (2008) found that majority of female teachers in England are professionally and academically qualified and, in most cases, have more experience than their male counterparts. Thus, contextual differences seem to account for women's academic qualifications and could influence the representation in school headship.

The data suggested that in situations where women possess the requisite academic and professional qualifications, they are reluctant to apply for such positions.

....Sometimes, we blame the system for the low representation of females in school leadership. But, have we asked ourselves as to whether women apply for the positions or not? Sometimes, we hold the needed qualifications but are unwilling to apply for [headship] positions available [FSUH-2].

One thing I have observed about our colleagues is that they are unwilling to apply for headship even if they qualify to do so. This is a problem in this part of the country [FUH-3].

These comments suggest that most women are unwillingness to climb the career ladder to become heads of SHSs. Grady [22] (1992) found that women with all the qualifications to become administrators were not employed in administrative positions and discovered that a major impediment was women's unwillingness to apply for administrative positions. Similarly, Mbilinyi and Omare [38] (2000) argue that there is a likelihood that many women who have qualifications, expertise and aptitude would not apply for positions of leadership in education management. Kusi [39] (2004), in his study of under-representation of women in secondary school headship in Bedfordshire in England found that although most women had the requisite qualification of headship, only the unmarried, divorced and those with adult children ascended to headship position. These women seemed to have time for their career development.

Last, but not the least, the data suggested that the female teachers' failure to formulate career development plans that includes headship accounted for their under-presentation in the headship positions.

What I have observed is that most of the female headteachers on my staff have no plans or intentions of becoming heads in future. This is contrary to what I have seen about the male staff.....[FUH-2]

Most of the female teachers have no plans to lead this school when I have retired. In fact, they have no headship aspiration and they seem to be satisfied with their teaching job![FUH-4].

These comments suggest that female teachers do not plan their career to include headship, which tends to affect their progression. Failing to plan to include headship could also affect their decision to undertake leadership and management programmes and, hence, their career progression. On the contrary, FUH-2, commented that it is uncharacteristic for a male teacher to teach for many years without moving into management role. She commented 'it is irresponsible on the part of men to be in the teaching profession for many years without moving into management. They work to fulfill this expectation!' 
Thus, the study revealed that a combination of socio-cultural, organizational and womenrelated factors account for women's under-representation in SHS headship in the study area.

\section{CONCLUSIONS AND RECOMMENDATIONS}

Based on the findings of the study, a number of conclusions could be drawn. Firstly, women are under-represented in SHS headship in the study area because they do not get the needed support to win competition for headship as recruitment panels are often dominated by males. It is, therefore, recommended that the Ghana Education Service directorate that is responsible for recruitment of school heads should ensure that women are fairly represented on recruitment panels. This could erode any misconceptions female applicants have about the composition of the panels, and eliminate any element of bias in the recruitment processes.

Although delegation could be used as training ground for acquisition of leadership skills, females teachers appeared to be reluctant to accept tasks delegated to them by their leaders because of lack of competence, pre-occupation with domestics roles, and contentment with teaching job. It is recommended that the Ghana Education Service authorities in the study area should re-orient and sensitize the female teachers on the importance of delegation in acquisition of leadership skills. Perhaps, the introduction of deliberate mentoring policies that would enable the teachers to be supported to develop leadership skills, and organization of leadership seminars could motivate them to develop interest in headship. The teachers who lack interest in headship because of commitment to domestics issues could be supported to manage the multiple roles and responsibilities more meaningfully.

Traditional Ghanaian socialization processes of making females family-oriented and submit to men as well as social construction of gender roles and responsibilities weaken females' effort to climb into school headship. It is, therefore, recommended that the education authorities and key stakeholders in education such as parents in the study area should re-orient both males and females on gender issues in education in modern societies. This could disabuse their minds of some negative Ghanaian socialization processes and be exposed to modern contemporary issues and gender roles and gender and leadership.

The female teachers' reluctance to apply for headship even if they hold requisite qualifications, and their failure to plan their career to include headship affected their progression into such position in the schools. It is recommended that the female teachers with leadership potentials should be equipped with leadership skills and be encouraged and motivated to apply for headship vacancies when advertised. Also, the school leaders in the study area should collaborate with the Ghana Education Service directorate to organize career development seminars on school leadership for the female teachers. Such seminars could help them develop headship ambition and to plan to achieve that ambition.

\section{Reference List}

Rimmer, J. (2003). The Four Dimensions of Instructional Leadership: What School Leaders Must Do to Improve Teaching Effectiveness, University of Washington, America.

Robinson, V., Lloyd, C., \& Rowe, K. (2008), "The impact of leadership on student outcomes: An analysis of the differential effects of leadership types', Educational Administration Quarterly, 44(5), pp. 635-674.

Kusi, H. (2008). "Managing Junior Secondary Schools in Sunyani Municipality (Ghana): The challenges for headteachers and their professional development needs." An unpublished Doctor of Education thesis submitted to School of Education, University of Leicester, UK.

Mythili, N. (2017), " Representation of women in school leadership positions in India", NUEPA Occasional Paper 5.

Coleman, M. (2000),"The female secondary school in England and Wales: Leadership and management styles", Educational Research. Vol. 42,1.pp.13-21. 
Elms, M. (2004). Female Management (online). Available from: http://www.schoolzone.co.uk. (Accessed: 12/02/2018)

Schien. V. E. (2007), "Women in management reflection and projections", Women in Management Review, 22(1), pp.6-18.

Jane, S., Shalom, A., Bessie, K. \& Daisy, W. (2010), "You have been a servant to all: Melanesian Women' s Educational Leadership Experiences", School Leadership and Management, 30(1), pp. 65-76.

Martin, L. J.(2011). Women as Leaders in Education. Praeger: New York.

Shakeshaft, C. (1998), "Wild patience and bad fit: Assessing the impact of affirmative action on women in school administration", Educational Researcher, 27, pp. 10-12.

Mankoe, J.O. (2007), Educational administration and management in Ghana. Progressive Stars Printing Press: Accra.

Northouse, P. G. (2018). Introduction to leadership: Concepts and practice (4th ed.), Thousand Oaks: Sage Publications, Inc.

Makura, A. H. (2008), A Comparative Study of Lesotho and Zimbabwe Female Primary School Administrators with Respect to Their Effectiveness. An Unpublished M.ED. Dissertation submitted to Roma, The National University of Lesotho.

Bush, T. \& Jackson, D. (2003),"A preparation for school leadership: International perspectives", Educational Leadership and Administration, Vol.30, No.4, pp.417-429.

Simkins, T. (2005) “Leadership in Education: 'what works' or 'what makes sense'?" Educational Management Administration and Leadership, Vol. 33, No.1, pp.9-26.

Searby, L. \&Tripses, J. (2006),"Breaking the perception of "old boys networks": Women leaders learning to make the most of mentoring relationships", Journals of Women in Educational Leadership, 2, pp. 39-47.

Gobena, L. (2014).Major factors that affect female teachers' participation in school leadership: The case of public primary schools in Jimma Town. An Unpublished M.Phil. thesis, Jimma University, Ethiopia.

Shakeshaft, C. (2009). Women in Educational Management. Newbury Park: Sage.

Schmuck, P.A.(2000), "Changing women's representation in school management: A systems perspective", Biklen, S.K.\& Brannigan, M. (Eds.), Women and educational leadership, Leington, MA: Lexington, pp. 239-259.

Asamoah, L. M. (1996). Women and educational leadership in the Volta Region of Ghana. An Unpublished M. Phil. Thesis, University of Cape Coast.

Tallerico, M., \& Burstyn, J. (2006), 'Retaining women in the superintendency: The location matters", Educational Administration Quarterly, 32(1), pp. 642-665.

Grady, M. L. (1992), "Women in educational administration: Certified by not employed", Educational Considerations, 20(1), 33-36.

Ortiz, F. I., \& Marshall, C. (1988), "Women in educational administration" In Boyan, N.(Ed.) Handbook of research on educational administration, Longman: New York, pp. 123-144.

Gall, M. D., Gall, J. P. \& Borg, W. R. (2007) Educational Research: An introduction (8th ed.), Pearson International Edition: Boston.

Patton, M.Q. (1990), Qualitative evaluation and research methods (2nd ed.). Sage: Newbury Park, CA.

Kusi, H. (2012). Doing qualitative research: A guide to researchers. Emmpong Press: Accra-New Town.

Charmaz, K. (1995), "Grounded theory", In J. Smith, J.H., Harre, R. \&Langenhove, L. V. (Eds.). Rethinking methods in psychology, Sage: London, pp.27-49.

Macionis, J. \& Gerber, L. M. (2010). Sociology. Pearson: Toronto Ontario.

Amuzu-Kpeglo, A. (2005), Approaches to administrative theory in education: The concept and context of the School. Cape Coast: IEPA, University of Cape Coast.

Shakeshaft, C. (1996). Women in educational administration, Unwin: Newbury Park, CA.

Jones, J. (2008). Management skills in schools: A resource for school leaders. Paul Chapman Publishing: London.

Cubillo, L. \& Brown, M. (2003), "Women into educational leadership and management: International differences?", Journal of Educational Administration, Vol.4, No.3, pp.278-291. 
Coleman, M. (1996), "Barriers to career progress for women in education: The perceptions of female headteachers", Educational Research, Vol.38, No.3, pp.317-332.

Agyeiwaa, R. \& Attom, L.E. (2018), "Gendered perceptions and challenges facing females in educational leadership positions", International Journal of Education, Learning and Development, Vol.6, No.7, pp.1-15.

Adler, N. \& Israeli, D. (1998),Women in management worldwide. M.E. Sharpe Inc.: New York.

McNamara, O., Howson, J., Gunter, H., Sprigade, A. \& Onat-Stelma, Z. (2008), "Women Teachers Career", NASUWT: Birmingham.

Mbilinyi, T. \& Omare, C. (2000). Gender relations and women's images in the media, Dare Salaam University Press: Dares Salaam.

Kusi, H. (2004), "Women Teach and Men Manage: Is this global perception reflected in the proposition of men to women in the senior management of middle and secondary schools in Bedfordshire?", An unpublished Master of Education dissertation submitted to the School of Education, De Montfort University, UK. 